\title{
CHARACTERISTICS OF CLIMATE-SMART AND COMMERCIALLY ASTUTE AGRICULTURAL EXTENSION PROFESSIONALS
}

\author{
Kadzere, C. T. ${ }^{1}$, Poswal, M. A. T. ${ }^{2}$, Nyangiwe, N. $^{3}$ \& Sonandi, A. ${ }^{4}$ \\ Correspondence author: C.T. Kadzere. Email: charles.kadzere@drdar.gov.za
}

\section{ABSTRACT}

Sixteen of the world's hottest years since 1860 were in the last 17 years. Greenhouse gases cause global warming and climate change $(C C)$. Climate change puts agriculture at a crossroads. The industry must adapt in order to feed a global population projected to reach 9.8 billion by 2050 and 11.2 billion by 2100. Adapting to CC requires agriculturalists at all levels to devise appropriate mitigation strategies. Business cannot be as usual. Climate change adds complexity to agriculture. To remain relevant, agricultural practitioners must be climatesmart (CS) in order to continue producing adequate, affordable, nutritious and safe food and fibre. Furthermore, agriculture is a business. It involves inputs, outputs, profit, loss, and is tied to the economic factors of production, land, labour, capital, and entrepreneurship. Therefore, the astute Agricultural Extension Professional/s (AEP/s) must be conversant not only with scientific and technical aspects of agriculture, its business and art, but also with emerging CC issues. The AEP must have relevant hard and soft skills that enable him/her to assist farmers adapt. This paper discusses the essential characteristics of a CS and commercially astute AEP in changing climate.

Keywords: Extension agent, Climate change, Skills

\section{INTRODUCTION}

Organisations such as Intergovernmental Panel on climate change (CC) (IPCC, 2013) and National Aeronautics and Space Administration (NASA, 2016; 2018) attribute CC to anthropogenic global warming caused by greenhouse gas (GGs) emissions into the atmosphere (Figure 1). The three main GGs responsible for global warming include carbon dioxide $\left(\mathrm{CO}_{2}\right)$, methane $\left(\mathrm{CH}_{4}\right)$, and nitrous oxide $\left(\mathrm{N}_{2} \mathrm{O}\right)$. Climate change puts agriculture at crossroads at a time when food production should double by 2050 to cater for growing population projected to reach 9.8 billion by 2050 (Food and Agriculture Organization of the United Nations (FAO), 2010), and 11.2 billion by 2100 (Alexandratos \& Bruinsma, 2012; United Nations Department of Economics and Social Affairs (UNDESA), 2017). The hottest 16 years on record since the recording of temperature which began in 1860 were in the last 17 years (Figure 2) with 2016,

\footnotetext{
${ }^{1}$ Professor \& Specialist Scientist for Animal Sciences, Döhne Agricultural Development Institute, Eastern Cape Department of Rural Development \& Agrarian Reform, Stutterheim, South Africa, Email: charles.kadzere@drdar.gov.za or kadzerect@gmail.com, ORCiD: 0000-0002-2120-5924

${ }^{2}$ Professor \& Specialist Scientist for Crop Sciences, Döhne Agricultural Development Institute, Eastern Cape Department of Rural Development \& Agrarian Reform, Stutterheim, South Africa, Email: maxwell.poswal@drdar.gov.za, ORCiD: 0000-0002-4143-9867

${ }^{3}$ Animal Scientist, Döhne Agricultural Development Institute, Eastern Cape Department of Rural Development \& Agrarian Reform, Stutterheim, South Africa, Email: nyangiwe1 @ gmail.com, ORCiD: 0000-0002-2685-1896

${ }^{4}$ Director of Extension \& Advisory Services, Eastern Cape Department of Rural Development \& Agrarian Reform, King William's Town, South Africa, Email: asonandi@yahoo.com, ORCiD: 0000-0003-4525-0102
} 
2015, and 2017 being the first, second and third hottest years on record respectively (Rohde, 2019).

Therefore, there is urgent need to develop appropriate farming approaches and systems that mitigate CC. The primary producers in agriculture include communal, small scale and commercial farmers. Primary producers are supported by private sector firms specific to each agricultural value chain. For example, the grain/crops value chains are serviced by private sector's seed breeding and distributing companies, farmers' co-operatives, fertilizer/crop chemicals companies, storage, grain marketing and grain distribution firms, grain millers, processors, insurance companies, and many others. Similarly, red meat and/or animal fibres value chains have private sector animal breeders, semen distributors, pre-mix, vitamin and minerals manufactures and feed millers and distributors, veterinary pharmaceutical companies, auctioneers, cattle feedlots, abattoirs, meat processors, wool/mohair washers, bailers, and marketers. The same applies to dairy, aquaculture, horticulture, wildlife, and many other agricultural value chains.

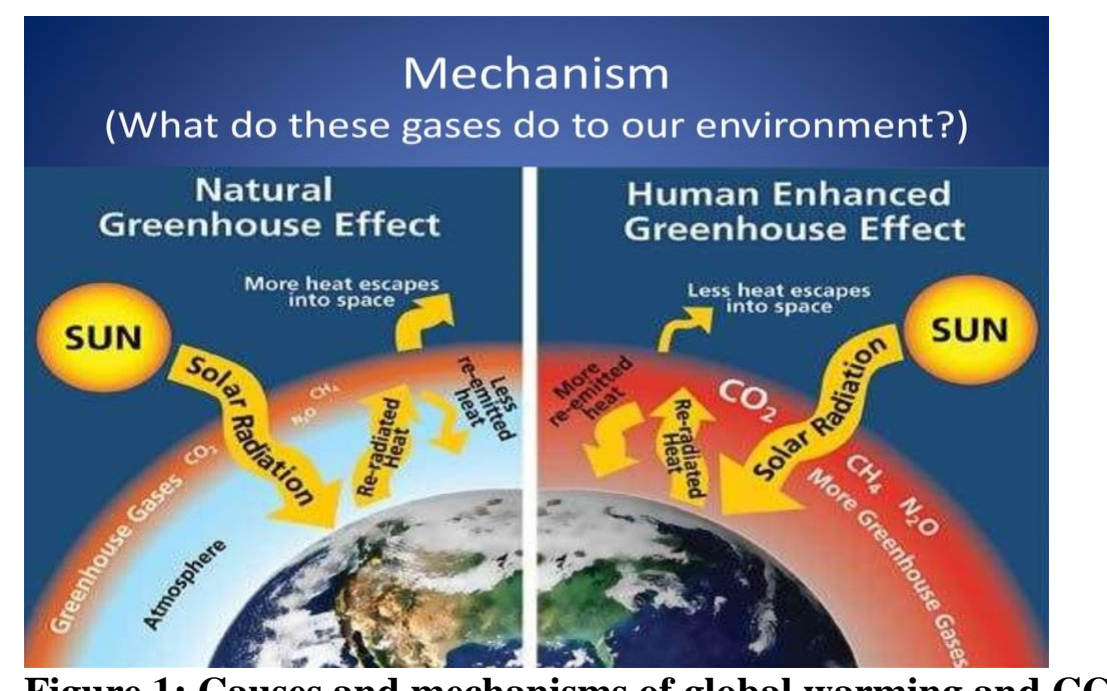

Figure 1: Causes and mechanisms of global warming and CC

Agricultural value chains are in turn supported by (a) scientists in agriculture faculties, government and private sector researchers, who develop technologies that enhance agricultural production, efficiency and profitability, and (b) the extension and advisory services that transfer technology through AEPs. The AEPs bring scientific discoveries and new technologies to improve production at grass-root farming levels. Their role is pivotal in any agricultural system. In some of todays' advanced agricultural systems, conventional extension and advisory services may be replaced and/or complemented by private consultants. This is especially so in industrial farming operations. Be that as it may, successful dissemination and adoption of new technologies by farmers is determinant of any farming system's performance; whether the role is fulfilled by AEPs or by consultants. Since AEP link research to farming communities, they are also change agents in agriculture. All actors in agriculture, including farmers, scientists, AEPs/consultants, and the private sector must collaborate to optimise and enhance production efficiencies in light of CC.

Global warming and resultant $\mathrm{CC}$, challenges agriculture in several ways. This is because agriculture is sensitive to extreme weather events such as floods, hailstorms, droughts, increases in animal and plant pests and diseases, and to changing rainfall patterns as well as to 
seasonal variability. Such events impact agriculture, and yet, agriculture as a business, that must be profitable environmentally sensitive, socially responsible, and sustainable. Sustainable agriculture is farming that meets current and future societal needs for food and fibre production, preserves ecosystems' integrity, is healthy for lives, and does so by maximising the net benefit to society when all costs and benefits are considered (Altieri, 1996; Kadzere, 2018; Meissner, Scholtz \& Engelbrecht, 2013).

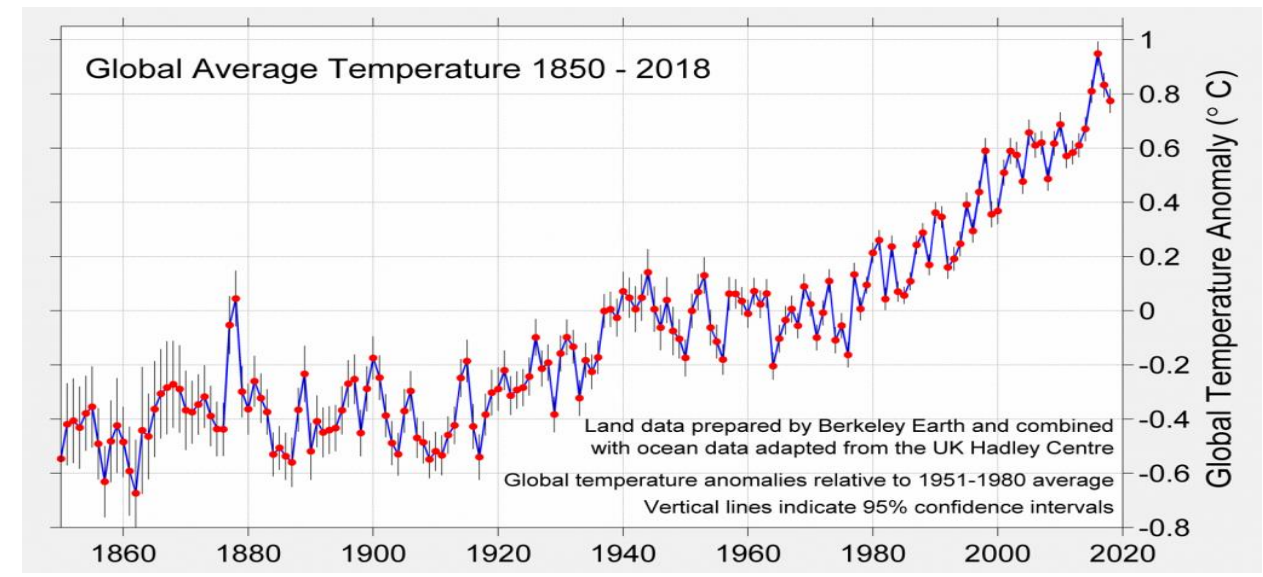

Figure 2: Global Temperature Report for 2018

The AEP finds oneself with the added responsibility of being a change agent, who works with farmers to mitigate $\mathrm{CC}$ and assists them adapt. Information on how extension and advisory services in Africa are adapting to $\mathrm{CC}$ is scant. This suggests apparent incognisance of the challenge $\mathrm{CC}$ poses to agriculture. Thus, the objectives of this study were to:

(i) Establish hard and soft skills essential for the AEP to successfully mitigate CC, and take stock of what is needed in order to be CS and commercially astute; and

(ii) Arrive at best approaches to mitigate CC in the AEP's service area.

Agriculture is a science, business and art in practice, guided by business principles in proper use of natural resources to produce food and fibre. Food and shelter are basic human needs without which no other human endeavour can be accomplished (Maslow, 1943). Mitigating the impact of CC on agriculture requires multidisciplinary approaches to find holistic solutions to this complex challenge. Resultantly, we hypothesise that the quality of science education and training for AEPs is related to their ability to be effective and contribute to developing strategies to mitigate $\mathrm{CC}$.

\section{METHODOLOGY}

Descriptive, correlational and observational literature of extension and advisory services systems from 1986 to 2015 were critically reviewed for functionality from the Kingdom (UK): Prager and Thompson (2014), Arnon (1989) Bunting (1986); Germany (DE): Hoffmann, Lamers and Kidd (2000), Hausen (1997), Grygo (1996), Farrington (1994) and the United States of America (US): Prokopy et al., (2015), Mase, Cho and Propokopy (2015), Wang (2014), Osmond et al., (2010) and Gardner (1990), and evaluated, then used as point of reference in the study. Professional AEP skills in reference countries, were compared and contrasted to those of their South African (SA) counterparts pre- and post-1994. The authors also drew extensively from combined professional experience of over 100 years in agriculture in Europe, America and Africa. 


\section{RESULTS AND DISCUSSION}

The job description of an AEP in SA is outlined in JobVine (2019). Although not exhaustive, it is similar to those in DE, UK and US. Across countries, the AEP's common charge is to transfer technology from research to farmers and increase production and efficiencies in agriculture. Further, today's AEPs must address issues related to CC (Jones (1997). Globally, $\mathrm{CC}$ is challenging agriculture. This is more so in Africa, where skills and resources to mitigate $\mathrm{CC}$ are scarce. Agriculture is already a complex undertaking, and CC only aggravates that situation. Climate change brings uncertainties that include variations in seasonal rainfall patterns, increased incidence and severity of heat stress on crops and livestock, droughts, changes in vegetation, hailstorms, floods, and impact on soils (IPCC, 2013). On account of CC induced uncertainties, AEPs should have solid science background, hard skills, and soft skills to enable them analyse and solve problems, and develop mitigation strategies. The soft skills include adaptability, ability to learn continuously, accountability, ability to communicate well, resolve conflict, manage time, create, think critically, use information technologies (ICT) and see the big picture whilst attending to detail on local impact of CC are critical.

\subsection{Hard skills}

Drawing from our combined in-country professional experiences, the AEPs in DE, UK and the US have earned at least a Bachelor's degree (BSc) in Agricultural Sciences. A majority hold Master of Science Degrees (MSc), and others Doctoral Degrees (Ph.D. / D.Sc.) in their respective areas of practice. These AEPs have basic Agricultural Sciences degree in common. This serves as entry point requirement for employment in extension and advisory services of their countries. To remain competitive, the AEPs in DE, UK and the US conduct research and publish findings in extension bulletins, professional popular and in scientific journals. These AEPs are numerate, analytical, and contribute to generating knowledge to mitigate $\mathrm{CC}$. The challenges posed by $\mathrm{CC}$ require AEPs to have solid preparation in natural sciences and the business aspects of animal, crop, pasture, horticulture, and wildlife production, as well as sustainable management of natural resources.

The solid natural and agricultural sciences background is crucial to address for example, one of the commonest challenge of $\mathrm{CC}$, heat stress. Heat stress in livestock and crop production is a major challenge posed by CC in agriculture worldwide. The CS and commercially astute AEP should understand the impact of heat stress processes at molecular, organismal and production levels in plants and animals as summarised in Figure 3 (Paupiere, 2014) and in animals in Figure 4 (Kadzere, 2018). This requires sound natural and agricultural sciences preparation at the BSc training level. There is a large body of knowledge on the effects of heat stress on animal production (Badinga et al., 1993; Collier et al., 1982; Faquay, 1981; Kadzere et al., 2002; Robertshaw \& Vercoe, 1980; Salem et al., 1982) and in plants (De Storme \& Geelen, 2014; Hasanuzzman et al., 2013; Matsui \& Omasa, 2002; Wahid et al., 2007). 


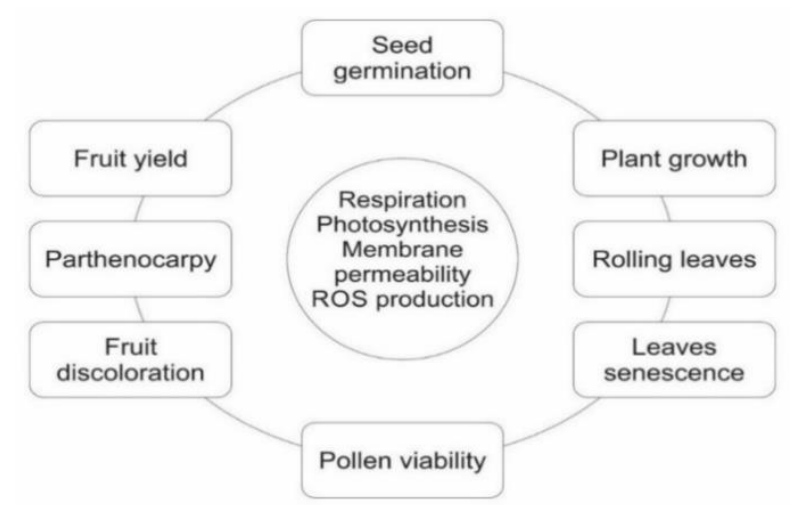

ROS: Reactive oxygen species

Figure 3: Impact of heat stress on plant production (Paupiere, 2014).

From professional experience in Africa, it can be said that the basic qualification for an AEP in Africa, including SA, was a Diploma in Agriculture. After 1994, this has been raised to a B. Agric., in SA, while reference countries of DE, UK and the US, require applicants to have earned at least a BSc degree in order to meet the basic employment needs of transferring technology from research to farming communities in order to boost agricultural production and attendant efficiencies, in sustainable ways.

The current basic requirement of a B. Agric. degree for employment as an AEP in SA is good progress. However, some universities, especially those in the then so-called "former homelands" offered and still offer B. Agric. degree programmes that are deficient in natural and agricultural sciences, including mathematics and statistics. And yet, natural and agricultural sciences as well as mathematical and statistical skills are essential in production agriculture, especially so for the AEP who serves in an advisory capacity to farmers (Oakley \& Garforth, 1997). Training in natural sciences spurs creativity and critical thinking skills that are essential to addressing complex challenges posed by CC. It may be pertinent therefore, for universities, the Department of Higher Education, and the Department of Agriculture to review such study programmes and fortify their scientific and mathematical components. That background is necessary in production agriculture (Kadzere et al., 2016), and crucial in mitigating CC. The B. Agric. degree programme offers Agriculture Management modules, and yet, graduates from these study programmes work mostly as AEPs, directly transferring technology and advising farmers, and rarely do they find placement in agricultural management as their study program prepares them for. Thus, there's an apparent disconnect between what the B. Agric. Study program offers and the job expectations on an AEP. Government should aid in rectifying this anomalous situation, by assisting AEPs to develop scientific and mathematical competence and acquire practical skills through on-the-job professional development and/or further education.

\subsection{Soft skills}

In addition to hard skills, the CS and commercially astute AEP must have soft skills that enable one to assist farmers adapt to $\mathrm{CC}$.

\subsubsection{Adaptability, ability to learn and keep learning}


Agricultural Extension Professionals must be adaptable to address agricultural production uncertainties resulting from $\mathrm{CC}(\mathrm{FAO}, 2016)$. The AEP must be willing and able to learn lifelong. The ability to learn is associated with reading. Therefore, the CS commercially astute AEP is an avid reader of one's subject matter, who keeps at the forefront of developments in her/his area of practice. It is only by keeping current, that the AEP can provide useful advisory services to farmers. Learning can be achieved through attending formal classes, subject-matter conferences, workshops, and symposia, and/or enrolling at institutions of higher learning for further study. Conducting research is an effective way to keep at the forefront of one's discipline. The Extension Service should consider incorporating research aspects in the job description of AEPs to help them keep abreast. After all, AEPs in reference countries work seamlessly with their research counterparts in integrated services delivery models, common to all three countries.

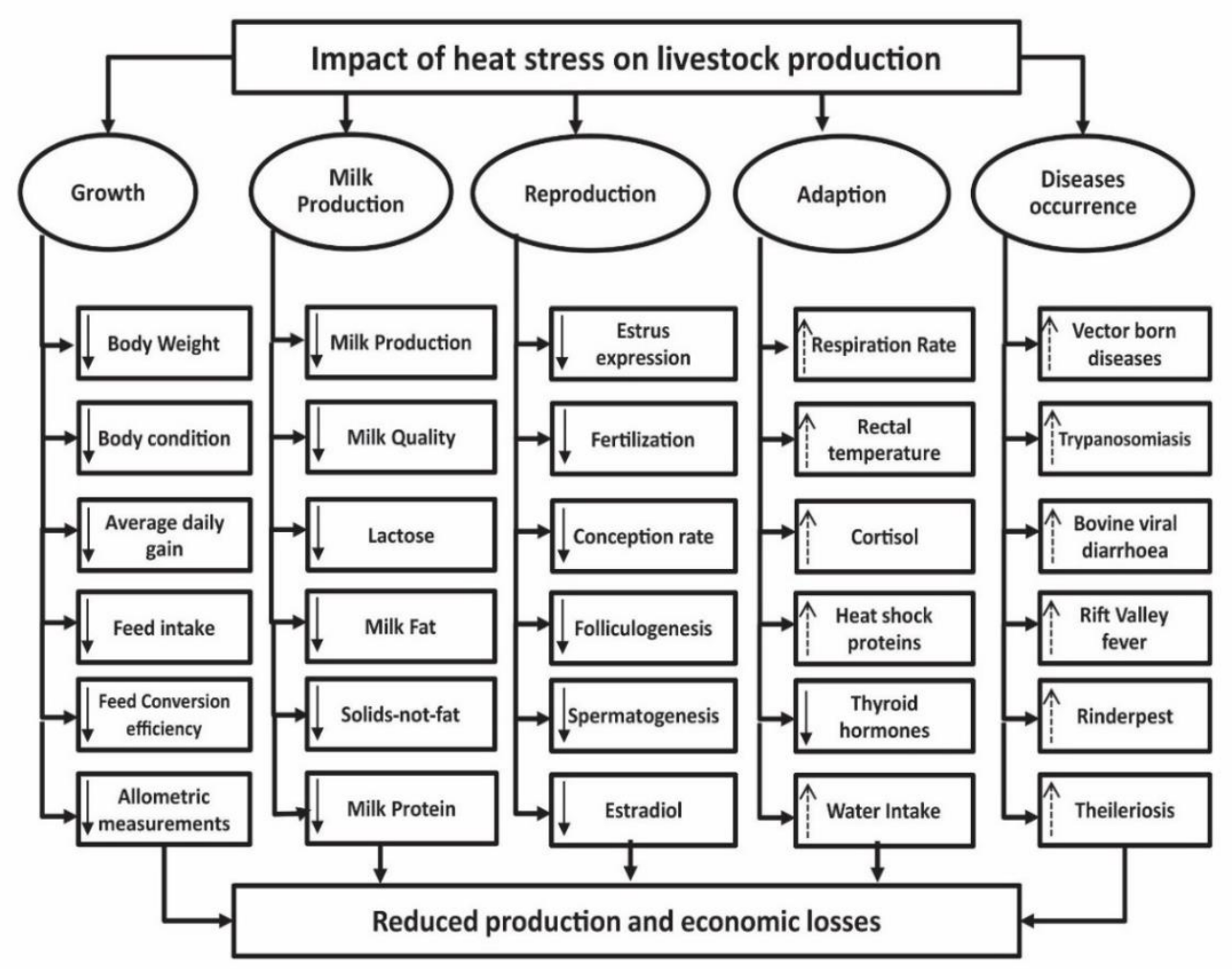

Figure 4: Impact of heat stress on animal production (Kadzere, 2018)

\subsubsection{Accountability}

Climate-smart and commercially astute AEPs are accountable to the farmers they serve, and they provide them with evidence-based advice (FAO, 2016). These AEPs are also accountable to the employer and they keep accurate records of daily work activities and take responsibility when something goes wrong. They register with professional bodies to keep in the know, and to access assistance to resolve issues of professional conduct when/and if they occur. The AEP must be accountable to oneself for continuous professional development.

\subsubsection{Active listener with good communication and conflict resolution skills}


An AEP must have deeper insights into scientific subject matter than the farmers, one advises. If farmers are more insightful into the subject matter than the AEP, they have nothing to gain and lose interest. Therefore, it's important to keep current. The AEP must understand farmers' challenges and provide specific advice, and not generic advice (Jones 1997 \& FAO, 2016) Climate change is local. Two adjacent farms may have different challenges, and need farmspecific mitigation strategies. Good listening helps the AEP arrive at farm-specific solution and is useful in conflict resolution.

\subsubsection{Collaborator with good interpersonal and time management skills}

Irrespective of being current in ones subject, there are times when the AEP is unable to resolve challenges, and requires collaboration with others AEPs, researchers, and academia. Climate change is multidisciplinary in nature, and challenges often require the involvement of various stakeholders, including researchers, academia, industry and government (FAO, 2016; Oakley \& Garforth, 1997)). In reference countries DE, UK, and US, the integration of agricultural advisory, research and training services is seamless. The European Union describes its agriculture continuum as Agriculture Knowledge and Information System (AKIS) (MadsenØsterbye, 2014). In those systems, the CS commercially astute AEP must be a collaborator with good interpersonal skills. Such an AEP knows when and where to get assistance. Knowing when and where to get help is excellent professional judgement and good time management.

\subsubsection{Attends to detail, but sees the big picture}

The CS commercially astute AEP understands global warming challenges, and attends to specific farm details to assist clients mitigate $\mathrm{CC}$ at the local level, and arrive at economically viable and sustainable options.

\subsubsection{Creative and critical thinker}

Agriculture involves biological systems including animals, crops, the environment, and also socio-economics. This requires the AEP to be creative and think critically.

\subsubsection{Experiments and learns together with farmers}

Climate change brings uncertainty to farming. Climate-smart and commercially astute AEPs experiment and learn with farmers and arrive at optimum mitigation strategies, through data collection and analysis in their areas of service (DFID, 2004). Good data enables AEPs to provide informed area-specific solutions to local challenges.

\subsubsection{Utilises information and communication technology}

Strategic use of ICT is useful in any industry and agriculture is no exception. The CS and commercially astute AEP uses technology to access one's farming clientele. However, this cannot substitute the occasional farm visit for one-on-one advisory. Further, the AEP can keep records of one's daily work and farm visits electronically, instead of in paper files. The AEP uses technology to enhance clientele decision making in the short, medium and long terms, by modelling CC in one's area. In addition, the CS and commercially astute AEP uses ICT to manage knowledge, create databases for commodities, regions, agro-ecological zones, soil and 
other physical information, including weather, and rainfall, which enables one to reach Clientele Interest Groups fast and simultaneously.

Using ICT enables the CS and commercially astute AEP to network on social media platforms that enhance one's services to farmers. The ICT has applications (apps) that AEPs can employ to assist farmers manage enterprises better. Such apps include weather data monitoring apps, farm management apps, livestock and crop production and management apps, among others. $\mathrm{CC}$ requires the AEP and all stakeholders in agriculture, to be life-long learner. Used strategically ICT provides opportunities for professional development through webinars, distance education, teleconferencing with peers and thought leaders in one's discipline (Dileepkumar, Dixit \& Balaji, 2005). The complexity of CC challenges requires stakeholders to collaborate and find holistic solutions to mitigate its effects. Also, ICT can be used to improve time management and accountability to oneself and to farmers.

\section{CONCLUSION AND RECOMMENDATIONS}

Agriculture provides for food and shelter. Without meeting these basic needs, all other efforts in human endeavour are futile. It is no coincidence that developed and developing countries with high performing economies provide unequivocal support for their nations' agriculture. Extension and advisory service is a crucial $\operatorname{cog}$ in any agricultural system. To address CC challenges, the AEP should not only be an expert in one's area of speciality, but also a change agent, who works with farmers to develop strategies and assist them adapt. For the AEP to succeed, one must be CS and commercially astute. Therefore, relevant education and continuous on-the-job skills upgrade and professional development is essential.

Climate-smart and commercially astute AEPs understand the scientific basis of anthropogenic global warming and CC. They are knowledgeable on sciences of production agriculture in their areas of expertise and keep at the forefront of new developments by reading extensively and participating in research, professional conferences, workshops, webinars, and registering in discipline-specific bodies. Technology drives rapid generation of knowledge. This requires the CS and commercially astute AEP to read avidly, learn continuously, and be techno-savvy. The digital revolution is evolving into wholesome integration of the biological, the physical, and the technical spheres. This demands the AEP to use ICT proficiently, and network to improve one's impact. Used properly, social networks are invaluable to extend one's professional reach.

Agriculture is a science, a business, and an art. The industry faces complex challenges, exacerbated by CC. Therefore, AEPs must collaborate within and across disciplines, locally and indeed globally to finds solutions. In addition to a strong science background, AEPs must understand the art and business aspects of agriculture. The bottom line for any farmer is: "How can my farming enterprise, aquaculture, crop, livestock, etc., optimise profitability and sustainability?" Thus, AEPs must provide solutions to make agriculture economically viable, environmentally sustainable, and socially responsible. In order to empower AEPs and mitigate CC, National and Provincial Departments of Agriculture, perhaps in collaboration with faculties of agriculture in their provinces should:

- Provide district, provincial and country CC mitigation strategies, and set up relevant infrastructure to monitor of weather.

- Provide CS professional development opportunities to AEPs, including being technosavvy, and design instruments to monitor progress. 
- Exploit the deep penetration of ICT on all classes of farming communities, even in remote rural areas, to provide holistic approaches to the use of technology to address challenges of CC including in (a) farmer decision making, (b) providing ICT models that assist farmers move from short to medium and long term planning, (c) creating social networks for collaboration between the AEP, scientist and indigenous knowledge in farming, (d) improve the link between government and university researchers and farmers, (e) planning at ward, district, provincial and regional levels to mitigate CC, and (f) provide farmer specific interventions on the one hand and apply ICT tools to develop and manage knowledge.

- Facilitate collaboration of AEPs across government departments, universities, private sector to address $\mathrm{CC}$ holistically.

- Work with universities to fine-tune curricula and strengthen scientific and business training in agriculture. In developed countries, graduates who later work as scientists or as AEPs obtain the same qualifications at BSc degree level. Those who opt for extension have the same natural sciences background as the ones who go into research. Business and other skills are taught at induction, when joining the Extension and Advisory Services. This is crucial because, every farmer is interested in advice that improves their bottom line.

- Encourage and reward sustainable agricultural practices that curb the release of soil carbon into the atmosphere such as conservation agriculture and/or minimum tillage.

In addition, the CS and commercially astute AEP should:

- Have strong work ethics and scientific competence to benefit farmers from one's services.

- Employ ICT tools to develop stratified databases for experts and farming clienteles in order to streamline communication and information dissemination.

- Collaborate with researchers, universities, and the private sector through ICT tools and build communities of practice to share information, ideas and resolve complex multidimensional challenges of $\mathrm{CC}$ to agriculture.

- Experiment, learn with farmers and scientists to develop appropriate CC extension programmes and mitigate local challenges, thus, act locally, think and impact globally.

- Collect and analyse local weather and production data and learn by doing to mitigate the impact of $\mathrm{CC}$ on agriculture, including drought, heat stress, and plant and animal pests.

- Be techno-savvy and judiciously use ICT and professional networks, which will increasingly be important in era of the fourth industrial revolution.

- Have production agriculture insights to enable the imagination and creation of visual images that assist farmers arrive at sound decisions in the scientific, art, and business components of agriculture.

- Have a balanced mix of soft and hard skills to command respect from farmers and maintain an open mind, which is necessary to address ever-changing situations due to CC.

- Seek to improve one's insights into the subject-matter through continuous professional development and skills upgrade on adaptive strategies to mitigate $\mathrm{CC}$.

- Engage farmers and promote dialogue in order to understand individual farmers, learn, communicate, and assist them mitigate $\mathrm{CC}$ challenges at their specific localities. 


\section{ACKNOWLEDGEMENTS}

Authors have no conflict of interest. Views expressed are solely those of the authors and may not necessarily reflect those of the employer. Karen Puchert is thanked for artwork, Figures 3 and 4.

\section{REFERENCES}

ALEXANDRATOS, N. \& BRUINSMA, J. 2012. World agriculture towards 2030/2050: The 2012 revision. ESA Working Paper 12-03. FAO. Rome, Italy.

ALTIERI, M.A. 1996. The science of sustainable agriculture. $2^{\text {nd }}$ ed. Boca Raton: CRC Press. ARNON, I., 1989. Agricultural research and technology transfer. London: Elsevier.

BADINGA, L. THATCHER, W.W., DIAZ, T., DROST, M. \& WOLFENSON, D., 1993. Effect of environmental heat stress on follicular development and steroidogenesis in lactating Holstein cows. Theriogenology, 39(4):797-810.

BAKER, H.R. 1989. Extension linkages and community development. In Foundations and changing practices in extension (pp.47-57). Toronto: Thompson Educational Publishing.

BUNTING, A.H. 1986. Extension and technical change in agriculture. In Investing in rural extension: Strategies and goals (pp.37-50). London: Elsevier Applied Science Publishers.

COLLIER, R.J., BEEDE, D.K., THATCHER, W.W., ISRAEL, L.A. \& WILCOX, C.J. 1982. Influences of environment and its modification on dairy animal health and production. $J$. Dairy Sci., 65(11):2213-2227.

DE STORME, N. \& GEELEN, D. 2014. The impact of environmental stress on male reproductive development in plants: Biological processes and molecular mechanisms. Plant Cell Environ, 37(1):1-18.

DFID. 2004. Adaptation to climate change: The right information can help the poor cope: Factsheet series (07) - Impact of climate change on poverty, and exploring tools adaptation to climate change UK. Available from http://www.povertyenvironment.net/node/1240

DILEEPKUMAR, G., DIXIT, S. \& BALAJI, V. 2005. Agricultural Extension with Information \& Communication Technology (ICT) Mediated Open Learning Methods (ODL) Methods: A Case Study from Rural South India. In Proceedings of Community Informatics Research Network 2005 (CIRN 2005) http://www.cirn2005.org/) Conf. Cape Peninsula Univ. SA.

FOOD AND AGRICULTURE ORGANIZATION OF THE UNITED NATIONS (FAO). 2016. Compendium: Climate-smart agriculture and extension. Supporting agricultural extension towards climate-smart agriculture. An overview of existing tools.

FOOD AND AGRICULTURE ORGANIZATION OF THE UNITED NATIONS (FAO). 2010. Livestock solutions for CC. Available from http://www.fao.org/gleam/results/en, and http;//www.fao.org/in-action/enteric-methane

FAQUAY, J.W. 1981. Heat stress as it affects animal production. J. Anim. Sci., 52(1):164-174.

FARRINGTON, J. 1994. Public sector agricultural extension: Is there life after structural adjustment? Available from http://dlc.dlib.indiana.edu/dlc/bitstream/handle/10535/3742/odi_agri2.pdf?sequence=1

GARDNER, J.C. 1990. Responding to farmers' needs: An evolving land grant perspective. Amer. J. Alter. Agric., 5(4):170-173. 
GRYGO, H. 1996. Landwirtschaftliche Beratung - Quo Vadis? Ausbildung und Beratung, [Agricultural advisory services - Where are you going? Training and advisory services] 5(96):88-89.

HASANUZZMAN, M., NAHAR, K., ALAM, M.M., ROYCHOWDHURY, R. \& FUJTTA, M. 2013. Physiological and molecular mechanisms of heat stress tolerance in plants. Int. J. Mol. Sci., 14(5):9643-9684.

HAUSEN, H. 1997. Gut beraten mit Gebuehren. Ausbildung und Beratung, [Well advised with fees - Training and advisory services] 1(97):15-17.

HOFFMANN, V. 1996. Landwirtschaftliche Beratung: Wohin - Part 2. Ausbildung und Beratung, [Agricultural advisory services - Where to? Training and advisory services] 1(96):10-12.

HOFFMANN, V., LAMERS, J. \& KIDD, A.D. 2000. Reforming the organization of agricultural extension in Germany: Lessons for other countries. Available from https://www.researchgate.net/profile/John_Lamers/publication/42766081_Reforming_t he_Organsation_of_Agricultural_Extension_in_Germany_Lessons_for_Other_Countrie s/links/09e41513077f1513dd000000/Reforming-the-Organsation-of-Agricultural-

Extension-in-Germany-Lessons-for-Other-Countries.pdf

INTERGOVERNMENTAL PANEL ON CC (IPCC). 2013. CC: The physical sciences basis. Available from https://www.ipcc.ch/report/ar5/wg1/

JOBVINE. 2019. Agricultural extension officer job description. Available from www.jobvine.co.za/job-description/agricultural-extension-officer/

JONES, G.E. 1997.The history, development and the future of Agricultural Extension in Improving Agricultural Extension - A reference manual by Burton E. Swanson et al., FAO, Rome.

KADZERE, C.T. 2018. Environmentally smart animal agriculture and integrated advisory services ameliorate the negative effects of CC on production. S. Afri. J. Anim. Sci., 48(5):842-857.

KADZERE, C.T. MURPHY, M.R., SILANIKOWE, N. \& MALTZ, E., 2002. Heat stress in lactating dairy cows: A review. Livest. Prod. Sci., 77(1):59-91.

KADZERE, C.T. POSWAL, M.A.T., NGADA, L.L., DAYIMANI, B., COETZEE, L. \& BESE, D.L. 2016. Unlocking Africa's agricultural development through public-private partnerships, supportive curricula and agriculture friendly policy. Available from https://repository.ruforum.org/system/tdf/Kadzere\%20unlocking.pdf?file=1\&type=nod e\&id=36092\&force $=$

MADSEN-ØSTERBYE, J. 2014. AKIS and advisory services in Denmark: Report on the inventory (WP3) of the PRO AKIS project. Available from proakis.webarchive.hutton.ac.uk/sites/www.proakis.eu/files/Country\%20Report\%20De nmark\%2006\%2006\%202014.pdf

MASE, A.S., CHO, H. \& PROKOPY, L.S. 2015. Agricultural advisors' perceptions of CC risk influence adaptation attitudes. J. Environ. Psychol., 41:166-176.

MASLOW, A.H. 1943. A theory of human motivation. 128 pp. ISBN 978.1365991493.

MATSUI, T. \& OMASA, K., 2002. Rice (Oryza sativa L.) cultivars tolerant to high temperature at flowering: Anther characteristics. Ann. Bot., 89(6):683-687.

MEISSNER, H.H., SCHOLTZ, M.M. \& ENGELBRECHT, F.A., 2013. Sustainability of the South African livestock sector towards 2050. Part 2: Challenges, changes and required implementations. S. Afri. J. Anim. Sci., 43(3):298-319.

NATIONAL AERONAUTICS AND SPACE ADMINISTRATION (NASA). 2016. Causes of CC: Natural causes of CC. Available from http://www.ces.fau.edu/nasa/module4/causes-2.php 
NATIONAL AERONAUTICS AND SPACE ADMINISTRATION (NASA). 2018. Longterm warming trend continued in 2017. Available from https://climate.nasa.gov

OAKLEY, P., \& GARFORTH, C. 1997. Guide to Extension training. FAO. ISBN 92-5101453-1.

OSMOND, D.L., NADKARNI, N.M., DRISCOLL, C.T., ANDREWS, E., GOLD, A.J., ALLRED, S.R.B., BERKOWITZ, A.R., KLEMENS, M.W., LOECKE, T.L., MCGARRY, M.A. \& SCHWARZ, K. 2010. The role of interface organizations in science communication and understanding. Front. Ecol. Environ., 8(6):306-313.

PAUPIERE, M., VAN HEUSDEN, A.W., \& BOVY, A.G. 2014. The metabolic basis of pollen thermos-tolerance: Perspectives for Breeding. Metabolites, 2014, 4, 8890920:doi: 10.3390/metabo4040889.

PRAGER, K. \& THOMPSON, K. 2014. AKIS and advisory services in the United Kingdom. Available from www.proakis.edu/publicationsand

PROKOPY, L.S., MORTON, J.G., ARBUCKLE, J.R., MASE, A.S. \& WILKE, A. 2015. Agricultural stakeholders' views on CC: Implications for conducting research and outreach. Bull. Am. Meteorol. Soc., 96(2):181-190.

ROBERTSHAW, D. \& VERCOE, J.E. 1980. Scrotal thermoregulation of the bull (Bos spp.). Aust. J. Agric. Res., 31(2):401-407.

ROHDE, R. 2019. Global Temperature Report for 2018. Available from http://berkeleyearth.org/2018-temperatures/

ROLLS, M.J., JONES, G.E. \& GARFORTH, C. 1986. The dimensions of rural extension. In Investing in rural extension: Strategies and goals (pp.5-18). London: Elsevier Applied Science Publishers.

SALEM, M.H., YOUSEF, M.K., EL-SHERBINY, A.A. \& KHALILI, M.H. 1982. Physiology of sheep and goats in the tropics. In Animal Production in the Tropics (pp.148-157). New York: Praeger.

UNITED NATIONS DEPARTMENT OF ECONOMICS AND SOCIAL AFFAIRS (UNDESA). 2017. The world population prospects: The 2017 revision. Available from Www.un.org >news > population

WAHID, A., GELANI, S., ASHRAF, M. \& FOOLAD, M. 2007. Heat tolerance in plants: An overview. Environ. Exp. Bot., 61(3):199-223.

WANG, S.L. 2014. Cooperative extension system: Trends and economic impact on U.S. agriculture. Choices, 29(1):1-8.

WHALE, W.B. 1989. Technology transfer revisited: Changing practices. In Foundation and changing practices in extension (pp.108-117). Toronto: Thompson Educational Publishing. 